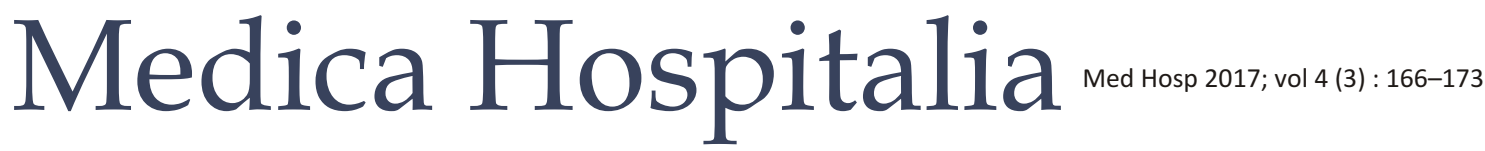

Original Article

\section{Pengaruh Pemberian Vitamin E terhadap Kadar Malondialdehid Plasma dan Hasil Uji Emisi Otoakustik pada Pekerja Terpapar Bising}

\author{
Muyassaroh, Devia Arnita, Zulfikar Naftali
}

Departemen Ilmu Kesehatan THT-KL FK Universitas Diponegoro / KSM KTHT-KL RSUP Dr. Kariadi Semarang

\begin{abstract}
Abstrak
Latar belakang : Bising dapat menyebabkan kerusakan koklea secara metabolik dengan terbentuknya reactive oxygen species (ROS) dengan cara menginduksi peroksidasi lipid dan dapat merusak DNA sehingga terjadi kematian sel terutama outer hair cell (OHC). Vitamin E merupakan antioksidan yang mendonorkan ion hidrogen pada tahap propagasi peroksidasi lipid sehingga menghasilkan produk yang tidak radikal dan menghentikan siklus peroksidasi lipid. Malondialdehid (MDA) adalah salah satu produk yang dihasilkan dari peroksidasi lipid. Kerusakan $\mathrm{OHC}$ dapat dideteksi dengan uji emisi otoakustik. Penelitian ini bertujuan untuk membuktikan vitamin E dapat menurunkan kadar MDA plasma dan memperbaiki hasil uji emisi otoakustik pada pekerja yang terpapar bising.

Metode : Penelitian eksperimental dengan desain randomized control trial, double-blind di pabrik kayu semarang pada bulan Desember 2015. Subyek penelitian sebanyak 32 pekerja terpapar bising dibagi menjadi 2 kelompok yaitu kelompok perlakuan $(n=16)$ yang mendapatkan vitamin E $400 \mathrm{IU}$ per oral dan kelompok kontrol $(n=16)$ yang mendapatkan plasebo. Dilakukan pemeriksaan kadar MDA plasma dan emisi otoakustik sebelum dan 10 hari setelah pemberian vitamin E. Perbedaan kadar MDA plasma sesudah pemberian vitamin E antara kelompok perlakuan dan kontrol dianalisis dengan uji $t$ tidak berpasangan dan perbedaan perbaikan hasil uji emisi otoakustik antara kelompok perlakuan dan kontrol dengan uji Fisher's exact.

Hasil : Dari 36 subyek penelitian yang memenuhi kriteria inklusi, dibagi menjadi 18 orang pada kelompok perlakuan dan 18 orang kelompok kontrol. Dua orang drop-out dari kelompok perlakuan dan 2 orang drop-out dari kelompok kontrol, sehingga analisis dilakukan pada 16 orang pada kelompok perlakuan dan 16 orang pada kelompok kontrol. Kadar MDA plasma setelah pemberian vitamin $\mathrm{E}$ tidak berbeda bermakna $(p>0,05)$ dibandingkan sebelumnya. Kadar MDA plasma sesudah pemberian vitamin $\mathrm{E}$ tidak terdapat perbedaan yang bermakna $(p>0,05)$ dibandingkan kelompok kontrol. Penurunan kadar MDA plasma pada kelompok perlakuan tidak berbeda bermakna $(p>0,05)$ dengan kontrol. Perbaikan hasil uji emisi otoakustik pada kelompok perlakuan tidak berbeda bermakna $(p>0,05)$ dengan kontrol.
\end{abstract}

\author{
The effect of giving vitamin $E$ \\ to plasma malondialdehyde levels \\ and the results of autoacoustic emission tests \\ on workers exposed to noise
}

\author{
Abstract
}

Background : Noise caused cochlear damage metabolically by producing the reactive oxygen species (ROS) and will induce lipid peroxidation that deleterious DNA and finally triggers cells death especially the outer hair cells (OHC). Vitamin E is an antioxidant that handover the hydrogen ion to the propagation phase of lipid peroxidation producing the non radical product and stop the lipid peroxidation cycle. Malondialdehyde (MDA) is one of the product that being produced from lipid peroxidation. Otoacoustic emissions test can detect the $\mathrm{OHC}$ damage. The objectives of this study was to prove that vitamin E can decrease the plasma MDA level and improve the otoacoustic emissions test result in the noise-exposed workers.

Methods : Experimental study with randomized control trial, double-blind design at wood factory in Semarang on December 2015. The subjects are 32 noise-exposed workers divided into 2 groups i.e treatment group $(n=16)$ received $400 \mathrm{IU}$ vitamin $\mathrm{E}$ orally and control group $(n=16)$ received placebo. Plasma MDA level and otoacoustic emissions test being examined before and 10 days after vitamin $E$ supplementation. The difference of plasma MDA level after vitamin E supplementation between the 2 groups are being analyzed with unpaired t test and the difference of the improvement of otoacoustic emissions tests results between the 2 groups are being analyzed with Fisher's exact test.

Results : From 36 subjects that appropriate with the inclusion criteria are being divided to 18 subjects to the treatment group and 18 subjects to the control group. Two subjects are being dropped out from the treatment group and 2 subjects are being dropped out from the control group, and finally, 16 subjects are being analyzed in the treatment group and 16 subjects are being analyzed in the control group. There is no significant difference $(p>0.05)$ of plasma MDA level after vitamin E supplementation 
Simpulan : Vitamin E tidak dapat menurunkan kadar MDA plasma dan tidak memperbaiki hasil uji emisi otoakustik pada pekerja terpapar bising.

Kata kunci : Vitamin E, malondialdehid, emisi otoakustik, pekerja terpapar bising compared to before supplementation. There is no significant difference $(p>0.05)$ of plasma MDA level after vitamin E supplementation compared to control group. The reduction of plasma MDA level in treatment group had no significant difference $(p>0.05)$ with the control group. There is no significant difference ( $p>0.05$ ) of the improvement of otoacoustic emissions tests results in treatment group compared to the control group

Conclusion : Vitamin E can't decrease neither the plasma MDA level nor improve the otoacoustic emissions tests results in noiseexposed workers.

Keywords : Vitamin E, malondialdehyde, otoacoustic emissions, noise-exposed workers

\section{PENDAHULUAN}

Noice Induced Hearing Loss (NIHL) adalah gangguan pendengaran akibat terpapar bising dalam jangka lama dan biasanya akibat bising dari lingkungan kerja. ${ }^{1} \mathrm{NIHL}$ merupakan salah satu target penurunan prevalensi kejadian gangguan pendengaran di masyarakat. Upaya pencegahan telah dilakukan dengan Hearing Conservation Program (HCP) atau Program Konservasi Pendengaran. Program ini terdiri dari empat bagian utama, yaitu pengawasan kebisingan, perlindungan pendengaran, tes pendengaran dan pelatihan. Pengendalian kebisingan dengan pelindung telinga telah banyak dilakukan karena biaya relatif lebih murah, namun banyak ditemukan kendala dalam pemakaian alat pelindung telinga. Kendala yang ditemukan seperti tingkat kedisiplinan pekerja, mengurangi kenyamanan kerja, dan menganggu pembicaraan. $^{2}$

Kerusakan utama akibat paparan bising terdapat pada outer hair cell (OHC) koklea dan kerusakan ini bersifat ireversibel. ${ }^{3}$ Bising merusak koklea secara metabolik dan mekanik. Teori terkini kerusakan metabolik pada koklea akibat paparan bising berfokus pada stres oksidatif dengan pembentukan reactive oxygen spesies (ROS). ROS terdeteksi di jaringan koklea segera setelah paparan bising dan bertahan 7-10 hari setelah terpapar bising, meluas dari bagian basal sampai apeks organ korti. ${ }^{4}$ ROS dapat menyebabkan kerusakan karena bereaksi dengan DNA, protein, molekul sitosol, reseptor permukaan sel, dan lipid membran. ROS yang diproduksi oleh mitokondria akan menginduksi peroksidasi lipid dan menghasilkan produk perantara berupa malondialdehid (MDA). MDA telah digunakan secara luas sebagai biomarker lipid peroksidasi. ${ }^{5}$

Uji emisi otoakustik sangat berguna untuk mendeteksi awal kerusakan koklea. Uji ini dapat digunakan untuk mendeteksi kurang pendengaran. ${ }^{6}$

Penelitian Le Prell dan Miller J (2007) menunjukkan bahwa kerusakan sel rambut koklea dapat dicegah dengan antioksidan. Antioksidan mencegah kerusakan dengan mengikat molekul radikal bebas sehingga mengubahnya menjadi zat yang tidak berbahaya. ${ }^{7}$ Penelitian ini menunjukkan bahwa kombinasi vitamin A, C, E dan magnesium dosis tinggi yang diberikan satu jam sebelum paparan bising, satu kali per hari selama 5 hari sangat efektif mencegah kurang pendengaran permanen akibat bising. ${ }^{7}$

Vitamin E merupakan antioksidan yang terdapat dalam lemak sel. ${ }^{8}$ Vitamin E bereaksi dan mengurangi radikal peroksil sehingga menghambat siklus lipid peroksidasi. ${ }^{9}$ Kapoor dkk (2011) menunjukkan bahwa vitamin $\mathrm{E}$ dan carbogen inhalan dapat menurunkan stres oksidatif dan mencegah terjadinya Temporary Threshold Shift (TTS). ${ }^{10}$

Tujuan dari penelitian ini adalah untuk mengetahui pengaruh vitamin E terhadap kadar MDA plasma dan hasil uji emisi otoakustik pada pekerja terpapar bising.

\section{METODE}

Penelitian dilakukan di pabrik kayu PT SY Semarang pada bulan Desember 2015 dengan besar sampel sebanyak 16 orang tiap kelompok. Kriteria inklusi adalah pekerja pabrik yang berusia antara 18-55 tahun, masa kerja $>2$ tahun, bekerja pada ruangan dengan tingkat kebisingan $>85 \mathrm{~dB}$, pemeriksaan liang telinga dan membran timpani dalam batas normal, hasil uji emisi otoakustik refer pada salah satu atau kedua telinga, dan bersedia mengikuti penelitian sampai selesai serta menandatangani lembar informed consent. Pekerja dieksklusikan jika mengkonsumsi obat-obatan lainnya yang dapat meningkatkan risiko efek samping seperti antikoagulan, memiliki hobi, pekerjaan tambahan atau tempat tinggal yang terpajan bising. Subyek penelitian akan didrop-out jika tidak patuh meminum obat, mengundurkan diri dari penetian dan timbul efek samping yang berat.

Data yang dikumpulkan dari 40 pekerja pabrik PT. SY adalah pemeriksaan berat badan dan tinggi badan, pemeriksaan liang telinga dan membran timpani dengan menggunakan otoskop mini FO merk Heine dengan pneumatic bulb oleh tenaga terlatih, uji emisi otoakustik pada telinga kanan dan kiri oleh tenaga terlatih, 
pengambilan sampel darah vena sebanyak $3 \mathrm{cc}$ oleh tenaga terlatih sebelum pemberian vitamin E, kemudian sampel darah vena dikirim ke laboratorium GAKI FK Undip untuk pemeriksaan kadar MDA plasma. Pekerja yang memenuhi kriteria inklusi dilakukan randomisasi dengan simple random sampling system blok, untuk menentukan kelompok perlakuan atau kelompok kontrol. Kelompok perlakuan mendapatkan kapsul vitamin E dengan dosis 400 IU 1 kali sehari selama 10 hari. Pekerja mengisi diary minum obat dan penggunaan alat pelindung telinga. Kelompok kontrol mendapatkan placebo (Equal tablet) dengan dosis 1 kali sehari selama 10 hari. Kedua kelompok dilakukan uji emisi otoakustik dan pengambilan sampel darah vena kembali pada hari ke-10 setelah pemberian vitamin E atau plasebo.

Kadar MDA plasma diperoleh dengan menggunakan metode Human MDA ELISA Elabscience. Rerata kadar MDA plasma sesudah pemberian vitamin E dibandingkan dengan rerata kadar MDA plasma sebelum pemberian vitamin $\mathrm{E}$, dibandingkan kadar MDA plasma sesudah pemberian vitamin E antara kelompok perlakuan dan kontrol, penurunan kadar MDA plasma dibandingkan antara kelompok perlakuan dan kontrol. Penurunan kadar MDA plasma dikategorikan menjadi (1) menurun, jika kadar MDA plasma sesudah diberikan vitamin $\mathrm{E}$ lebih rendah dibandingkan sebelum diberikan vitamin E, (2) tidak menurun, jika kadar MDA plasma sesudah diberikan sama dengan atau lebih tinggi daripada sebelum diberikan vitamin $\mathrm{E}$.

Emisi otoakustik diperiksa dengan menggunakan alat uji emisi otoakustik skrining merk Otoread oleh tenaga terlatih. Hasil pemeriksaan yang diperoleh berupa pass atau refer. Perbaikan hasil uji emisi otoakustik setelah pemberian vitamin E dikategorikan menjadi (1) membaik, jika hasil uji emisi otoakustik setelah diberikan vitamin E pass dimana sebelum diberikan vitamin E refer, (2) tidak membaik, jika hasil uji emisi otoakustik setelah diberikan vitamin $\mathrm{E}$ refer dimana sebelum diberikan vitamin E refer atau pass.

Variabel yang dinilai adalah kadar MDA plasma sesudah pemberian vitamin E dibandingkan dengan kadar sebelum pemberian vitamin E dengan uji $\mathrm{t}$ berpasangan, kadar MDA plasma sesudah pemberian vitamin E dibandingkan dengan kontrol dengan uji $\mathrm{t}$ tidak berpasangan, penurunan kadar MDA plasma dibandingkan dengan kontrol dan perbaikan hasil uji emisi otoakustik setelah pemberian vitamin E dengan uji

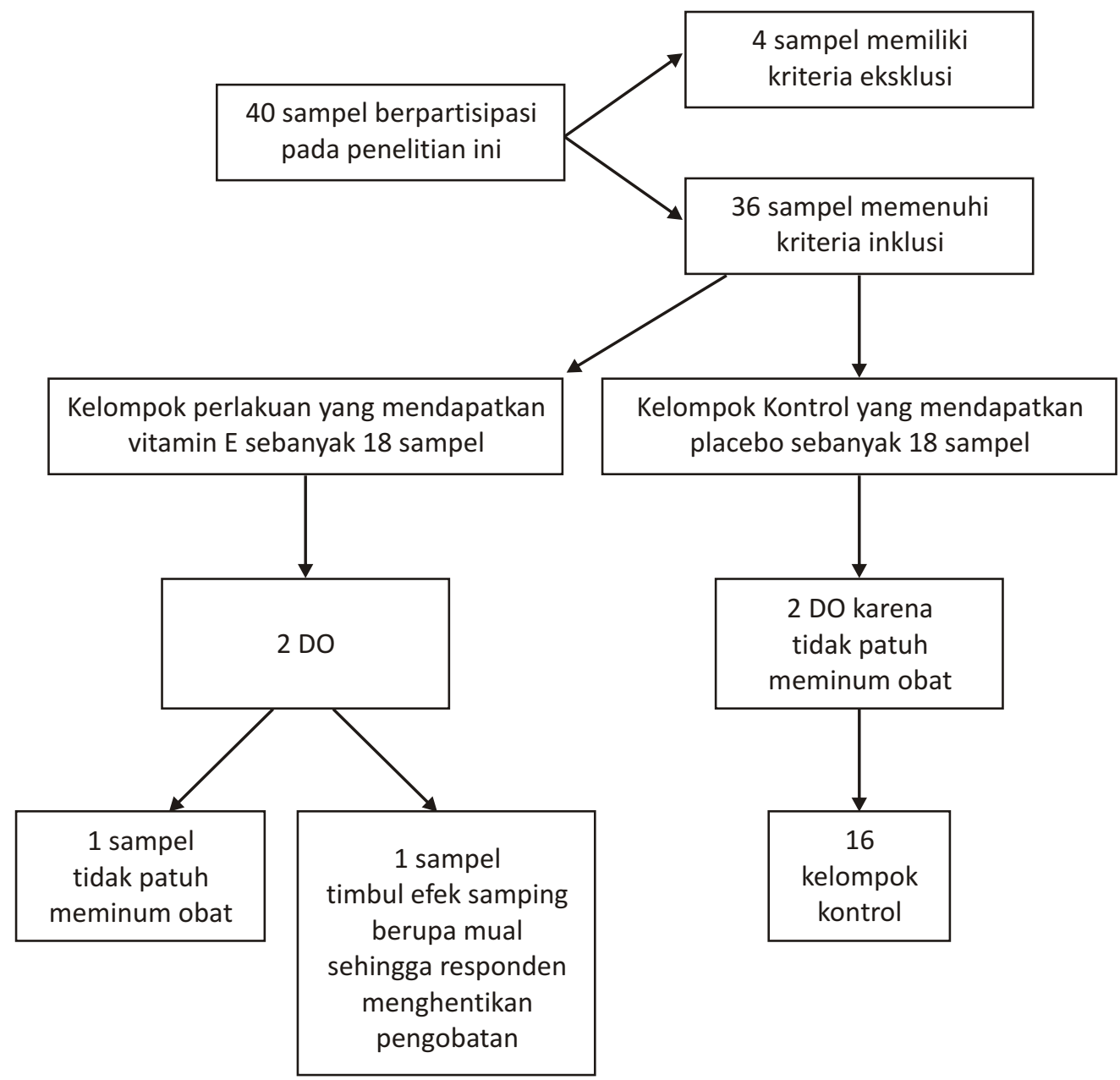




\section{TABEL 1}

\section{Karakteristik subyek penelitian}

Variabel $\underset{\substack{\text { Perlakuan } \\(\mathrm{n}=16)}}{ }$

Jenis kelamin

Laki-laki

Perempuan

Median usia (tahun)

Kelompok usia

$$
\begin{aligned}
& 16-25 \text { tahun } \\
& 26-35 \text { tahun } \\
& 36-45 \text { tahun } \\
& 46-55 \text { tahun }
\end{aligned}
$$

Median lama kerja (tahun)

Klasifikasi lama kerja

$$
\begin{aligned}
& <10 \text { tahun } \\
& 10-20 \text { tahun } \\
& >20 \text { tahun }
\end{aligned}
$$

Body Mass Index

BB kurang, ringan

BB normal

BB lebih, ringan

BB lebih, berat

Alat pelindung telinga

Rutin

Tidak rutin

Kebiasaan merokok

$\mathrm{Ya}$

Tidak

Indeks Brinkmann

Ringan
Sedang
Berat

Hasil uji emisi otoakustik

Refer bilateral

Refer unilateral
13

3

37,5 (22-49)

1

2

10

3

$17,5(3-21)$

3

11

2

2

11

1

2

3

13

7

9

7

0

0
Kontrol

(n=16)

15

1

39 (26-44)

0

1

15

0

$19(8-21)$

$0,468 * *$

Nila

0,3 *
$0,518 * *$

$0,754 * * * *$

$0,668 * * * *$

1

10

2

3

$0,5 * * * * *$

4

12

$0,715^{*}$

5

11

5

0

0

$0,011^{*}$

14

2

$0,688 * * *$ 
Fisher's exact. Penelitian in telah disetujui oleh Komisi Etik Penelitian Kesehatan / Kedokteran FK Undip/ RSUP Dr. Kariadi Semarang.

\section{HASIL}

Data kadar MDA plasma setelah pemberian vitamin E pada kelompok perlakuan dan kontrol dengan $p>0,05$.

Gambar 1 menunjukkan adanya peningkatan kadar MDA plasma setelah 10 hari pasca pemberian vitamin E yang bermakna $(p<0,05)$ pada kelompok perlakuan (Kadar MDA pre-test 32,52 $\pm 16,37 \mathrm{mcg} / \mathrm{mL}$; kadar MDA post-test 39, $58+10,16 \mathrm{mcg} / \mathrm{mL}$ ) maupun kontrol (Kadar MDA pre test 30,36 \pm 13,71 mcg/ mL; kadar MDA post test 37,08 + 11,04 mcg/ mL) (Gambar 1).

Tidak didapatkan perbedaan yang bermakna $(p$ $>0,05$ ) pada kadar MDA plasma setelah pemberian vitamin E selama 10 hari pada kelompok perlakuan dan kontrol (Tabel 2).

Sebagian besar subyek penelitian tidak mengalami penurunan kadar MDA plasma. Tidak terdapat perbedaan yang bermakna $(p>0,05)$ antara kelompok perlakuan dengan kontrol dalam hal penurunan kadar MDA plasma setelah pemberian vitamin E (Tabel3).

Sebagian besar subyek penelitian tidak mengalami perbaikan hasil uji emisi otoakustik setelah diberikan vitamin E. Perbaikan hasil uji emisi otoakustik

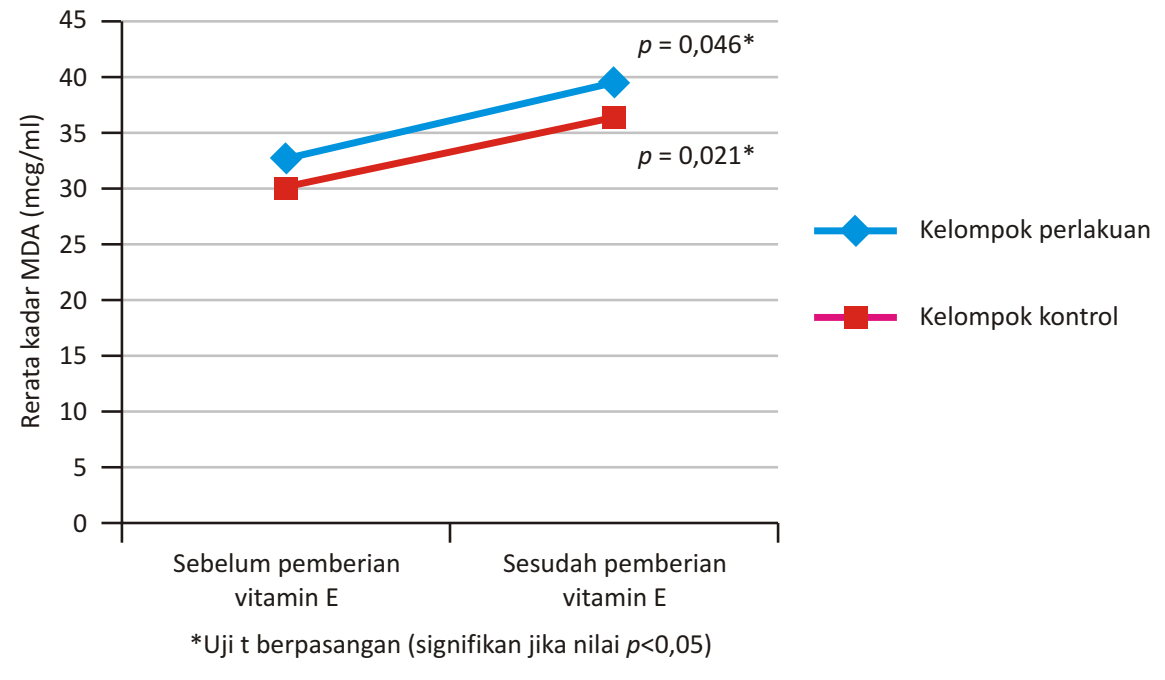

Gambar 1. Grafik perbedaan rerata kadar MDA plasma sebelum dan sesudah pemberian vitamin E pada kelompok perlakuan dan kontrol

TABEL 2

Perbedaan rerata kadar MDA plasma setelah pemberian vitamin E pada kelompok perlakuan dan kontrol

Kelompok

Kelompok perlakuan $(\mathrm{n}=16)$

Kelompok kontrol $(n=16)$

\section{Rerata (s.b)}

$39,58(10,16)$

$37,08(11,04)$
Nilai $p$

0,509

Perbedaan rerata (IK95\%)

$2,51(5,15-10,17)$

\section{TABE 3}

Penurunan kadar MDA setelah pemberian vitamin E pada kelompok perlakuan dan kontrol

\begin{tabular}{|c|c|c|c|}
\hline \multirow[t]{2}{*}{ Kelompok } & \multicolumn{2}{|c|}{ Kadar MDA setelah pemberian vitamin $\mathrm{E}$} & \multirow{2}{*}{$\underset{p}{\text { Nilai }}$} \\
\hline & Menurun & Tidak menurun & \\
\hline Perlakuan $(n=16)$ & $5(31,3 \%)$ & $11(68,8 \%)$ & 0,5 \\
\hline Kontrol (n=16) & $4(25 \%)$ & $12(75 \%)$ & \\
\hline
\end{tabular}

Uji Fisher's Exact 


\section{TABEL 4}

Perbaikan hasil uji emisi otoakustik setelah pemberian vitamin E pada kelompok perlakuan dan kontrol

\begin{tabular}{|c|c|c|c|}
\hline \multirow[t]{2}{*}{ Kelompok } & \multicolumn{2}{|c|}{ Perbaikan hasil uji emisi otoakustik } & \multirow{2}{*}{$\begin{array}{c}\text { Nilai } \\
\boldsymbol{p}\end{array}$} \\
\hline & Membaik & Tidak membaik & \\
\hline Perlakuan ( $n=16)$ & $5(31,3 \%)$ & $11(68,8 \%)$ & 0,685 \\
\hline Kontrol $(n=16)$ & $3(18,8 \%)$ & $13(81,3 \%)$ & \\
\hline
\end{tabular}

Uji Fisher's Exact

pada kelompok perlakuan dan kontrol tidak didapatkan perbedaan yang bermakna $(p>0,05)$ (Tabel 4$)$.

\section{DISKUSI}

\section{Karakteristik subyek penelitian}

Subyek penelitian merupakan karyawan pabrik kayu di Kota Semarang yang sebagian besar berjenis kelamin laki-laki dengan rentang usia 22-49 tahun. Sebanyak 912.362 jiwa atau $73,96 \%$ penduduk kota Semarang merupakan penduduk usia produktif (umur 15-65 tahun). Mata pencaharian terbanyak penduduk Kota Semarang adalah buruh industri sebanyak 225.987 jiwa 15,sehingga masalah kesehatan pada pekerja industri di Semarang perlu diperhatikan.

\section{Pengaruh vitamin E terhadap kadar MDA plasma}

Rerata kadar MDA pada kelompok perlakuan tidak berbeda bermakna dengan kontrol $(p>0,05)$ setelah pemberian vitamin E selama 10 hari. Penelitian ini tidak dapat membuktikan pengaruh vitamin $\mathrm{E}$ terhadap kadar MDA plasma pekerja terpapar bising. Hal ini serupa dengan penelitian yang dilakukan oleh Meagher dkk (2001) yang menilai efek vitamin E terhadap peroksidasi lipid pada orang sehat. Penelitian tersebut merupakan uji klinis random tersamar ganda dengan subyek penelitian menerima vitamin E dengan dosis 200, 400, 800, 1200 atau 2000 IU per hari selama 8 minggu ( $\mathrm{n}=5$ pada masingmasing kelompok). Pemeriksaan kadar antioksidan endogen berupa vitamin $\mathrm{E}$ di plasma darah dilakukan sebelum diberikan suplemen vitamin $\mathrm{E}$ dan semua subyek penelitian memiliki kadar vitamin E plasma yang normal. Biomarker peroksidasi lipid yang dinilai adalah 4-HNE urin. Hasilnya tidak terdapat efek yang signifikan terhadap kadar peroksidasi lipid setelah pemberian vitamin E dengan semua dosis tersebut selama 8 minggu. ${ }^{11}$ Keterbatasan penelitian Meagher adalah kriteria inklusi tanpa bukti biokimiawi peningkatan stress oksidatif sebelum diberikan vitamin E sehingga memiliki kelemahan, dan jumlah sampel yang terlalu sedikit menyebabkan kesalahan statistik tipe II memberikan variasi yang cukup banyak. Penyebab lainnya adalah potensi prooksidan dari antioksidan termasuk vitamin E. Efek kompetisi prooksidan dan antioksidan saling menggagalkan satu sama lainnya, namun tidak berhubungan dengan dosis. ${ }^{11}$ Kekurangan dari penelitian ini adalah tidak menilai kadar vitamin $\mathrm{E}$ plasma, sehingga tidak diketahui variasi kadarnya pada subyek penelitian sebelum diberikan intervensi. Jumlah sampel telah kami sesuaikan dengan penelitian terdahulu dan menambahkan $10 \%$ jumlah sampel untuk kemungkinan drop-out.

Rerata kadar MDA pre-test kelompok perlakuan $32,52 \pm 16,37 \mathrm{mcg} / \mathrm{mL}$ dan kontrol 30,36 $\pm 13,71 \mathrm{mcg} / \mathrm{mL}$ sedangkan rerata kadar MDA post-test kelompok perlakuan $39,58 \pm 10,16 \mathrm{mcg} / \mathrm{mL}$ dan kontrol 37,08 \pm $11,04 \mathrm{mcg} / \mathrm{mL}$. Penelitian Turkoglu (2003) menilai kadar MDA plasma pada 55 orang sehat (25 laki-laki dan 30 perempuan) dibagi menjadi 2 kelompok usia yaitu kelompok usia muda (21-40 tahun; 30,0 $\pm 4,6)$ dan kelompok usia tua (61-85 tahun; 72,7 $\pm 5,8)$. Kadar MDA plasma meningkat pada kelompok usia tua dibandingkan kelompok usia muda. Rerata kadar MDA plasma kelompok usia muda 2,55 $\pm 0,75 \mu \mathrm{mol} / \mathrm{L}$ sedangkan pada kelompok usia tua $3,96 \pm 1,12 \mu \mathrm{mol} / \mathrm{L}$ dengan nilai $p<0,001$. Jika dikonversikan ke dalam satuan $\mathrm{mcg} / \mathrm{mL}$ maka rerata kadar MDA plasma pada kelompok usia muda (21-40 tahun) adalah 32,4-59,4 $\mathrm{mcg} / \mathrm{mL}$ sedangkan pada kelompok usia tua (61-85 tahun) adalah 51,12 - 91,44 mcg/mL. Hasil pemeriksaan kadar MDA plasma sebelum dan sesudah pemberian vitamin E pada kelompok perlakuan maupun kontrol pada penelitian ini masih dalam batas normal.

Hanya $43,8 \%$ subyek penelitian pada kelompok perlakuan dan $31,3 \%$ subyek penelitian pada kelompok kontrol memiliki kebiasaan merokok dengan indeks Brinkmann ringan (100\%). Sumber radikal bebas eksogen pada pekerja dapat berupa asbestos, crystalline silica, batu bara, diesel, chromium, bleomisin, nitric oxide, ozone, radiasi dan merokok. ${ }^{12}$ Penilaian riwayat merokok dan nilai indeks Brinkman sudah dilakukan, namun zat-zat kimia yang menyebabkan peningkatan radikal bebas di pabrik tersebut tidak diobservasi.

BMI pada pekerja di penelitian ini sebagian besar memiliki nilai BMI normal (68,8\% kelompok perlakuan, $62,5 \%$ kelompok kontrol), berat badan lebih tingkat berat (12,5\% kelompok perlakuan, 18,8\% kelompok kontrol), berat badan lebih tingkat ringan $(6,3 \%$ kelompok 
perlakuan, 12,5\% kelompok kontrol). Penelitian yang dilakukan Olusi (2002) pada 50 orang dengan BMI normal $\left(19-25 \mathrm{~kg} / \mathrm{m}^{2}\right)$ dan 250 orang dengan obesitas $\left(30-50 \mathrm{~kg} / \mathrm{m}^{2}\right)$ tanpa riwayat merokok, diabetes melitus, hipertensi, hiperlipidemia, penyakit ginjal, penyakit liver atau kanker menunjukkan bahwa kadar MDA plasma secara signifikan lebih rendah pada kelompok dengan BMI normal $(p<0,001)$ daripada orang dengan BMI diatas $40 \mathrm{~kg} / \mathrm{m}^{2}$ dan terdapat korelasi yang positif antara BMI dan kadar MDA plasma $(\mathrm{r}=0,34, p=0,013)$. Dari hasil tersebut dapat disimpulkan bahwa obesitas tanpa adanya riwayat merokok, diabetes melitus, hiperlipidemia, penyakit ginjal atau liver menyebabkan peroksidasi lipid. ${ }^{13}$ Miller dkk (1998) melakukan penelitian tentang efek pola makan dengan peroksidasi lipid. Miller meneliti 123 orang sehat yang diberikan makanan kontrol yang sedikit buah, sayur dan produk susu, dengan 37\% kalori dari lemak selama 3 minggu kemudian dilakukan randomisasi menjadi 3 kelompok yaitu (1) diet kontrol, (2) diet yang kaya buah dan sayur, (3) kombinasi diet yang kaya buah, sayur, dan produk susu yang rendah lemak selama 8 minggu. Serum oksigen radikal, MDA dan breath ethane diukur pada akhir intervensi. Hasilnya menunjukkan terdapat peningkatan kemampuan antioksidan serum dan melindungi sel dari peroksidasi lipid pada kelompok 2 dan 3 dibandingkan dengan kelompok kontrol. ${ }^{14}$

Pengaruh vitamin E terhadap hasil uji emisi otoakustik Sebagian besar pekerja pada penelitian ini tidak patuh menggunakan alat pelindung telinga ( $81,3 \%$ kelompok perlakuan, $75 \%$ kelompok kontrol). Angka ketidakpatuhan ini lebih tinggi dibandingkan dengan penelitian Riyadina (2007) dimana pekerja yang patuh menggunakan alat pelindung saat bekerja sebanyak $68,1 \%$ sedangkan yang tidak patuh sebanyak 31,9\%. ${ }^{5}$ Ketidakpatuhan terhadap penggunaan alat pelindung telinga dapat meningkatkan risiko terjadinya NIHL. Alat pelindung telinga memiliki kemampuan mereduksi kebisingan sesuai dengan kapasitasnya masing-masing berdasarkan Noise Reduction Rating (NRR). Earplug dapat mengurangi kebisingan 8-30 dB, earmuff dapat menurunkan kebisingan $25-40 \mathrm{~dB}$, dan helm dapat mengurangi kebisingan 40-50 dB. ${ }^{1,15}$

Sebagian besar pekerja pada penelitian ini memiliki lama kerja 10-20 tahun (68,8\% kelompok perlakuan, $81,3 \%$ kelompok kontrol). Paparan bising dalam jangka waktu pendek dapat menyebabkan Temporary Threshold Shift (TTS) yang akan pulih kembali dalam waktu 24-48 jam. Seiring dengan berjalannya waktu biasanya dalam jangka waktu 10 tahun, paparan bising menyebabkan kerusakan OHC sehingga mengakibatkan Permanent Threshold Shift (PTS) yang bersifat ireversibel. Paparan bising kronik dengan intensitas di atas $85 \mathrm{dBA}$ dapat menyebabkan kerusakan OHC. ${ }^{16}$
Pemeriksaan emisi otoakustik dapat menilai fungsi OHC secara sensitif, obyektif dan mengidentifikasi secara dini kerusakan fungsi koklea. ${ }^{17}$ Adanya kelainan pada uji emisi otoakustik sebagai prediksi adanya peningkatan nilai ambang dengar. ${ }^{24}$ Hasil uji emisi otoakustik pada responden didapatkan refer bilateral pada kelompok perlakuan sebanyak 37,5\% dan kelompok kontrol 87,5\% sedangkan hasil refer unilateral pada kelompok perlakuan sebanyak 83,3\% pada kelompok perlakuan dan $16,6 \%$ pada kelompok kontrol. Dari responden tersebut diperkirakan sudah memiliki peningkatan nilai ambang dengar, kemungkinan terjadi TTS atau PTS. Penelitian yang dilakukan oleh Ismail dkk, dari 55 responden dengan NIHL, 34 (62\%) memiliki kurang dengar bilateral, 14 (26\%) memiliki kurang dengar sisi kiri saja, dan 7 (13\%) memiliki kurang dengar sisi kanan. Walaupun definisi standar dari NIHL adalah kurang dengar di kedua sisi, namun NIHL unilateral juga sering ditemukan. Studi yang dilakukan Fadzli menemukan pekerja penggergajian menderita kurang dengar unilateral dengan telinga kiri lebih buruk daripada telinga kanan. Penyebab NIHL unilateral tidak dipahami dengan baik kemungkinan pekerja menghadapkan salah satu telinga ke sumber bising mesin saat melakukan pekerjaan seharihari. ${ }^{17}$

Vitamin E tidak terbukti dapat memperbaiki hasil uji emisi otoakustik pada penelitian ini $(p>0,05)$. Patofisiologi kerusakan metabolik koklea akibat bising salah satunya dengan pembentukan ROS dalam koklea sehingga menginduksi terjadinya peroksidasi lipid yang akan menghasilkan produk radikal bebas yang bersifat merusak DNA sehingga menyebabkan kematian sel. Adanya produk peroksidasi lipid vasoaktif seperti isoprostane berpotensi mengurangi aliran darah koklea yang berhubungan dengan bising. Iskemia akibat paparan bising dan reperfusi selanjutnya akan menyebabkan pembentukan ROS.8 Vitamin E dapat mencegah peroksidasi lipid dengan menyapu radikal peroksil lipid. Vitamin E merupakan donor antioksidan yang memberikan elektron terhadap radikal peroksil lipid sehingga membentuk lipid hidroperoksida yang kurang toksik dan vitamin $\mathrm{E}$ radikal yang akan direduksi kembali menjadi vitamin E oleh vitamin C atau GSH. Vitamin E menghambat pembentukan peroksidasi lipid dengan mengurangi radikal peroksil. ${ }^{18}$ Vitamin E juga melindungi beta karoten dari oksidasi. Kombinasi vitamin A, C, E sebagai antioksidan dan magnesium akan lebih efektif dibandingkan pemberian antioksidan tunggal. Masing-masing zat ini memiliki mekanisme kerja yang saling melengkapi. Efek beta karoten bekerja untuk menyapu superoksida yang jika bereaksi dengan lipid akan membentuk produk peroksidasi lipid sehingga pengambilan superoksida akan mencegah terjadinya peroksidasi lipid. Vitamin E mendonorkan antioksidan yang akan bereaksi dan mengurangi radikal 
peroksil lipid sehingga menghambat siklus propagasi pada peroksidasi lipid. Vitamin C mengurangi radikal bebas pada fase aqueous yang berbeda dengan vitamin $\mathrm{E}$ yaitu dalam membran sehingga terjadi interaksi yang sinergis antara antioksidan lipofilik dan hidrofilik. Salah satu efek dari magnesium adalah mengurangi vasokonstriksi akibat paparan bising. Hal ini telah dibuktikan oleh Le Prell dkk (2007) yang menunjukkan bahwa pemberian kombinasi vitamin A, C, E dan magnesium pada tikus memiliki pergeseran nilai ambang ABR lebih kecil dibandingkan kelompok yang diberikan kombinasi vitamin A, C, E tanpa magnesium, magnesium saja dan kontrol. ${ }^{11}$

\section{Keterbatasan penelitian}

Penelitian ini memiliki beberapa keterbatasan yaitu : 1) Tidak menilai kadar vitamin E plasma sebelum dan sesudah diberikan vitamin E, 2) Tidak menilai asupan makanan yang dapat membiaskan antioksidan eksogen yang masuk bersamaan dengan vitamin E, 3) Penelitian ini sudah melakukan randomisasi sampel dengan simple random sampling, tetapi masih didapatkan perbedaan pada kelompok perlakuan dan kontrol mengenai hasil uji emisi otoakustik sebelum diberikan vitamin E, 4) Tidak dilakukan pemeriksaan timpanometri sebelum dan sesudah pemberian vitamin E. Hal ini berkaitan dengan hasil uji emisi otoakustik dapat refer jika terdapat kelainan di telinga tengah contohnya otitis media efusi, otosklerosis, dan timpanosklerosis.

\section{SIMPULAN}

Tidak terdapat perbedaan malondialdehid plasma dan hasil emisi otoakustik pekerja terpapar bising sebelum dan setelah pemberian vitamin $\mathrm{E}$.

\section{DAFTAR PUSTAKA}

1. Bashiruddin J, Soetirto I. Gangguan pendengaran akibat bising (noise-induced hearing loss). In: A.F.Soepardi, Iskandar N, Bashiruddin J, Restuti RD, editors. Buku ajar Ilmu Kesehatan Telinga Hidung Tenggorokan Kepala dan Leher. Jakarta: Balai Penerbit FKUI; 2007. p. 49-52.

2. Chao EL. Hearing conservation. In: Labor, editor. United States: Occupational Safety and Health Administration; 2002. p. 1-24.

3. Chavez J, Cano C, Souki A, Bermudez V, Medina M, Ciszek A, et al. Effect of cigarette smoking on the oxidant/antioxidant balance in healthy subjects. Am J Ther. 2007;14(2):189-93.
4. Wong ACY, Froud KE, Hsieh YS-Y. Noise-induced hearing loss in the $21^{\text {st }}$ century: A research and translational update. World J Otorhinolaryngol. 2013;3(3):58-70.

5. Ayala A, Munoz MF, Arguelles S. Lipid peroxidation: Production, metabolism, and signaling mechanism of malondialdehyde and 4-hydroxy-2-nonenal. Oxidative Medicine and Cellular Longevity 2014:1-31.

6. Marshall L, Miller JAL, Heller LM. Distortion-product otoacoustic emissions as a screening tool for noise-induced hearing loss. Noise \& health. 2001;3(12):43-60.

7. LePrell CG, Hughes LF, Miller JM. Free radical scavenger vitamin A, C, and E plus magnesium reduce noise trauma. Free Radical Biology \& Medicine. 2007;42:1454-63.

8. Burton $\mathrm{G}$, Joyce A, Ingold $\mathrm{K}$. Is vitamin $\mathrm{E}$ the only lipid-soluble, chain-breaking antioxidant in human plasma and erythrocyte membranes? Arch Biochem Biophys. 1983;221:281-90.

9. Schafer F, Wang H, Kelley E, Cueno K, Martin S, Buettner G. Comparing beta-carotene, vitamin $\mathrm{E}$ and nitric oxide as membrane antioxidants. Biol Chem. 2002;383:671-81.

10. Kapoor N, Mani KV, Shyam R, Sharma RK, Singh AP, Selvamurthy W. Effect of vitamin E supplementation on carbogen-induced amelioration of noise induced hearing loss in man. Noise Health. 2011;13:452-8.

11. A.Meagher E, Barry OP, Lawson JA, Rokach J, FitzGerald GA. Effect of vitamin E on lipid peroxidation in healthy persons. JAMA. 2001;285(9).

12. Vallyathan $\mathrm{V}$, Shi $\mathrm{X}$. The role of oxygen free radicals in occupational and environmental lung diseases. Environ Health Perspect 1997;1(1):65-177.

13. Olusi S. Obesity is an independent risk factor for plasma lipid peroxidation and depletion of erythrocyte cytoprotectic enzymes in humans. Int $\mathrm{J}$ Obes Relat Metab Disord. 2002;26(9):1159-64.

14. Miller ER, Appel LJ, Risby TH. Effect of dietary patterns on measures of lipid peroxidation. Results from a randomized clinical trial. Circulation. 1998;98:2390-5.

15. Bashiruddin J. Program konservasi pendengaran pada pekerja yang terpajan bising industri. Maj Kedokt Indon. 2009;59(1):14-9.

16. Hong O, Kerr MJ, Poling GL, Dhar S. Understanding and preventing noise-induced hearing loss. Disease-a-Month. 2013;59:110-8.

17. Spankovich C, Hood LJ, Silver HJ, Lambert W, Victoria M. Flood PM. Associations between diet and both high and low pure tone averages and transient evoked otoacoustic emissions in an older adult population-based study. J Am Acad Audiol. 2011;22:49-58.

18. Prell CGL, Bao J. Prevention of noise-induced hearing loss: Potential therapeutic agents. Noise-induced hearing loss Scientific advances. USA:Springer; 2012. p. 283-323. 